\title{
Biology of a Neotropical Harlequin Stink Bug, Runibia perspicua (F.)
}

\author{
Al Marsaro Jr, AR PanizzI, T LucinI \\ Lab of Entomology, Embrapa National Wheat Research Center, P.O. Box 3081, Passo Fundo, RS, Brasil
}

\section{Keywords}

Hemiptera, Heteroptera, Pentatomidae, nymph, adult, host plant

\section{Correspondence \\ AR Panizzi, Lab of Entomology, Embrapa National Wheat Research Center, P.O. Box 3081, Passo Fundo, RS 99001-970, Brasil; antonio.panizzi@embrapa.br \\ Edited by Marcelo N Rossi - UNIFESP}

Received 11 July 2017 and accepted 21 November 2017

Published online: 7 December 2017

(C) Sociedade Entomológica do Brasil 2017

\begin{abstract}
Laboratory and field studies were conducted with nymphs and adults of the Neotropical stink bug Runibia perspicua (F.) to evaluate their biology on plants. Total nymph mortality was ca. $13 \%$ on immature fruits of Brunfelsia australis Benth. (IFBA) and $90 \%$ on raw shelled peanuts, Arachis hypogaea L. (RSP); no nymphs survived on immature pods of green bean, Phaseolus vulgaris L., or on immature fruits of privet, Ligustrum lucidum Ait. Nymph developmental time was ca. 36 on IFBA and 55 days on RSP. Body weight was significantly greater when nymphs were raised isolated compared to those raised in groups. Adult feeding activity was greater than third instars on IFBA. Adult longevity on IFBA + cherry tomato, Solanum lycopersicum L. fruit, reached ca. 150 days. On IFBA, fecundity was 2.5 egg masses/female and 48.3 eggs/female; $25.6 \%$ of the eggs hatched. Adults did not reproduce on tomato. Body weight gain did not increase significantly for both sexes during the first four weeks of adult life on IFBA. In the field, plants of $B$. australis were surveyed in Passo Fundo, RS $\left(28^{\circ} 15^{\prime} \mathrm{S} ; 52^{\circ} 24^{\prime} \mathrm{W}\right)$. The majority of egg masses were deposited on the lower (abaxial) surface of leaves. Nymphs aggregated on immature fruits, and adults were seldom found on the plants. These are the first data on the performance of $R$. perspicua on $B$. australis indicating that this plant species is suitable to the bug's biology.
\end{abstract}

\section{Introduction}

The genus Runibia Stål (Hemiptera: Heteroptera: Pentatomidae) include six species of stink bugs distributed exclusively in the Neotropical Region (Zwetsch \& Grazia 2001). Their geographical distribution indicates that Runibia perspicua (F.) is the most common species in the South and in the Southeast Regions of Brazil; it also occurs in central Argentina and Paraguay, in Bolivia, and in Uruguay; its northern most distribution is Santa Cruz de la Sierra (Bolivia) in South America (latitude $17^{\circ} \mathrm{S}$ ) and Minas Gerais state in Brazil (latitude $20^{\circ} \mathrm{S}$ ) (Zwetsch \& Grazia 2001).

Stink bugs of the genus Runibia are medium to large (9.8$15.6 \mathrm{~mm}$ ) with ovoid body shape, generally colored yellowishreddish, with typical darkish-black spots on the dorsal surface
(Zwetsch \& Grazia 2001). They are considered, along with other eight genera of pentatomids (Pentatominae), as having aposematic coloration (Rider 1991, Zwetsch \& Grazia 2001).

Not much is known about the biology of $R$. perspicua, except for scattered references in the literature to its occurrence on different plant species. Several authors refer to its occurrence on pear, Pyrus communis L. (Rosaceae) (Monte 1939, Lima 1940, Bertels 1956, Buckup 1961), although apparently not reaching pest status on this cultivated fruit tree. It seems also to prefer plants of Solanaceae, such as those in the genus Brunfelsia, ornamental plants known in Brazil as "manacá" or "jasmim"; several authors refer to R. perspicua on different species of Brunfelsia in different states of the south and southeastern Brazil (Biezanko et al 1949, Buckup 1961, Silva et al 1968). 
Field surveys conducted at random in the central-north area of Rio Grande do Sul state, Brazil, in the locality of Passo Fundo $\left(28^{\circ} 15^{\prime} \mathrm{S}, 52^{\circ} 24^{\prime} \mathrm{W}\right)$ indicated that $R$. perspicua inhabits Brunfelsia plants (Brunfelsia australis Benth. and $B$. pilosa Plowman). Therefore, in this study, we report the results obtained in the laboratory to evaluate the performance of nymph and adult of $R$. perspicua feeding on immature fruits of one of the species (B. australis) on which they were mostly found. In addition, field surveys of nymphs and adults were conducted on this plant species, and their abundance colonizing the fruiting structures was recorded.

\section{Materials and methods}

\section{Laboratory studies}

Establishment of Laboratory Colony. Adults of R. perspicua were collected during May-July 2015 in Passo Fundo, RS, Brazil, on $B$. australis and were taken to the laboratory. Nymphs and adults were placed in clear plastic box $(25 \times$ $20 \times 20 \mathrm{~cm}$ ) to obtain eggs according to the methodology described by Silva \& Panizzi (2008). They were fed with immature fruits on a stem of $B$. australis, the base of which was wrapped with commercial cotton and placed in a glass vial with water. Food source was replaced when needed. Egg masses were removed and conditioned in Petri dishes $(9.0 \times 1.5 \mathrm{~cm})$ lined with moistened filter paper and then carried to an environmental chamber where experiments were performed. The environmental chamber was maintained at $25 \pm 1^{\circ} \mathrm{C}, 80 \pm 10 \% \mathrm{RH}$, and 14 -h photophase.

Nymph Survivorship and Development. Ten cages (plastic transparent cylinders $15 \times 6 \mathrm{~cm}$, made of two cups held together using double clips) each containing 10 nymphs on the first day of the second instar were used. Nymphs were fed with a piece of branch of $B$. australis holding one immature fruit, which was replaced weekly. During AprilMay 2015, nymphs were checked daily and the number of survivors recorded at each observation. Upon completing the nymphal development, percentage survivorship and total developmental time (from second instar to adult) was calculated, and females and males were weighed on the day of eclosion.

An additional study was carried out to test the suitability of other food plants, usually used to rear different species of stink bugs in the laboratory. These included raw shelled peanuts, Arachis hypogaea L., fresh green bean pods, Phaseolus vulgaris L., and immature fruits (berries) of privet, Ligustrum lucidum Ait. These three standard foods were compared with fruits of the preferred food plant $B$. australis. Individual nymphs were placed in plastic Petri dish $(6 \times 1 \mathrm{~cm})$ containing one of the foods, totalizing
40 dishes (10 dishes/food). Daily records were taken of individual nymphs. Percentage survivorship and developmental time at each instar and total (from second instar to adult) were calculated, and females and males were weighed on the day of eclosion.

Nymph and Adult Feeding Activity. To test the feeding activity of bugs on immature fruits of $B$. australis, third instar nymphs $(n=12)$ and adults ( $n=10 ; 6$ females and 4 males) were placed individually in crystal polystyrene boxes ( $11 \times$ $11 \times 3.5 \mathrm{~cm}$ ) lined with filter paper. One immature fruit of $B$. australis was placed inside each box, with water supplied using moistened cotton in a plastic container $(1 \mathrm{~cm}$ diameter). The numbers of feeding stylet sheath laid on the fruits were recorded after 24 and $96 \mathrm{~h}$. Mean ( \pm SE) number of sheaths laid by nymphs and adults (females and males) was calculated.

Adult Survivorship, Longevity, Reproduction, and Body Weight. Adult performance of $R$. perspicua was studied on immature fruit of B. australis during May-November 2015. Pairs $(n=10)$ were placed in each crystal polystyrene box $(11 \times 11 \times 3.5 \mathrm{~cm})$ lined with a filter paper. Each box contained one fruit, which was replaced twice per week. After 54 days, because no fruit of $B$. australis was available in the field, the bugs were continued to be fed with cherry tomato fruit, Solanum lycopersicum L. This food was chosen because it is also a Solanaceous plant, and it was easily found for purchase in grocery stores. Daily observations were made of adult mortality, female oviposition, eggs laid and hatched. Adult survival up to day 240, total longevity, percentage of ovipositing, preoviposition period, fecundity (mean number of eggs masses and eggs/female), and percentage of fertility were calculated. Fresh body weight $(\mathrm{mg})$ for both sexes was taken at adult emergence and at days 7, 14, 21, and 28 of adult life, using an electronic scale (Sartorius BP210S) (to the nearest $0.1 \mathrm{mg}$ ). Males and females that died were not replaced. Treatments were set up in a completely randomized design, and each pair was considered a replicate.

\section{Field studies}

Egg Mass Survey and Allocation on Different Plant Structures. During April 7-16, 2015, field samples were taken on four different days, resulting in 39 egg masses obtained from plants of $B$. australis. Leaves and fruits containing the egg masses were placed in plastic bags and taken to the laboratory. The number of eggs per mass, the number (\%) of eggs hatched, and the egg mass allocation on the plant, i.e., on fruits and on leaves (adaxial [upper] or abaxial [lower] surfaces), were recorded. 
Table 1 Development time (mean $\pm \mathrm{SE}$ ) and mortality of Runibia perspicua nymphs, feeding on immature fruits of Brunfelsia australis (IFBA), raw shelled peanuts (RSP), immature pods of green bean (IPGB), and immature fruits of privet (IFP), in the laboratory.

\begin{tabular}{|c|c|c|c|c|c|c|c|c|}
\hline \multirow[t]{2}{*}{ Food sources } & \multirow[t]{2}{*}{ Initial number } & \multicolumn{4}{|c|}{ Stadium duration (days) } & \multicolumn{2}{|c|}{$\begin{array}{l}\text { Total development time } \\
\text { (2nd-5th instar) (days) }\end{array}$} & \multirow[t]{2}{*}{$\begin{array}{l}\text { Total } \\
\text { mortality }(\%\end{array}$} \\
\hline & & 2nd & $3 r d$ & 4 th & 5th & Female & Male & \\
\hline IFBA $^{1}$ & 10 & $5.5 \pm 0.3[10]$ & $6.6 \pm 1.1[9]$ & $7.8 \pm 0.6[9]$ & $15.8 \pm 1.2[9]$ & $35.0 \pm 1.7[4]$ & $35.8 \pm 2.1[5]$ & 10 \\
\hline $\mathrm{IFBA}^{2}$ & 100 & - & - & - & - & \multicolumn{2}{|c|}{$37.3 \pm 0.9[83]^{3}$} & 17 \\
\hline RSP & 10 & $14.0 \pm 0.0[2]$ & $8.0[1]$ & $11.0[1]$ & $22.0[1]$ & $55.0[1]$ & - & 90 \\
\hline IPGB & 10 & $5.9 \pm 0.7(10)$ & - & - & - & - & - & 100 \\
\hline IFP & 10 & $4.1 \pm 0.3(10)$ & - & - & - & - & - & 100 \\
\hline
\end{tabular}

Number of individuals completing stadium given in brackets; survivorship of nymphs without completing stadium in parentheses.

${ }^{1}$ Nymphs raised isolated.

${ }^{2}$ Nymphs raised in groups.

${ }^{3}$ Females + males.

Nymph Feeding Activity on Fruits. During April 9-16, 2015, three field samples were taken of fruits of $B$. australis on which nymphs were aggregated. Fruits and nymphs collected were placed in plastic bags and taken to the laboratory. The number of nymphs and the number of feeding stylet sheaths deposited on the fruit surface were recorded. Data on the number of nymphs were separated in four classes (ranges of 1-10, 11-20, 21-30, $\geq 31$ nymphs) and correlated with the number of feeding stylet sheaths deposited on the fruit. We also ranked the fruit size (diameter) on which the bugs were found in three classes (ranges of 9-11, 12-14, and 15$17 \mathrm{~mm}$ ), and this was correlated with the number of nymphs colonizing each fruit, and with the number of feeding stylet sheaths laid on each fruit.

\section{Statistical analysis}

The number of stylet sheath per fruit deposited by different numbers of nymphs, number of nymphs and number of stylet sheath per fruit of different sizes, and number of stylet

Table 2 Fresh body weight (mean $\pm \mathrm{SE}$ ) of Runibia perspicua at adult emergence feeding on immature fruits of Brunfelsia australis (IFBA), isolated or in groups, in the laboratory.

\begin{tabular}{lll}
\hline Food source & \multicolumn{2}{l}{ Fresh body weight $^{1}(\mathrm{mg})$} \\
\cline { 2 - 3 } & Male & Female \\
\hline IFBA (isolated) $(n=10)^{2}$ & $177.8 \pm 7.5$ aA (5) & $166.7 \pm 2.1 \mathrm{aA}(4)$ \\
IFBA (in groups) $(n=100)$ & $121.3 \pm 4.9 \mathrm{bA}(46)$ & $114.0 \pm 4.4 \mathrm{bA}(37)$ \\
\hline
\end{tabular}

${ }^{1}$ Means followed by the same lowercase letters in each column and uppercase letters in each row do not differ significantly $(P<0.05)$ using Student's $t$ test.

${ }^{2}$ Initial number of nymphs. sheath deposited by insects of different stages after 24 and $96 \mathrm{~h}$ were submitted to analysis of variance (ANOVA) and means were compared using the Tukey test $(P<0.05)$. Data were first subjected to the Bartlett test to check for homogeneity of variances $(P<0.05)$ and then transformed to $(x+$ $0.5)^{1 / 2}$ when necessary.

The number of eggs per mass on different plant structures, fresh body weight of males and females, number of stylet sheath laid by nymphs and adults at 24 and $96 \mathrm{~h}$, and longevity of adults were compared using Student's $t$ test $(P<0.05)$. The percentage of eggs laid on different plant structures (leaf vs. fruit, and leaf abaxial vs. leaf adaxial) was calculated and compared using Pearson's chi-square test $\left(\chi^{2}\right)$. All statistical analyses were conducted using $\mathrm{R}$ program v.3.3.1 (R Development Core Team 2016).

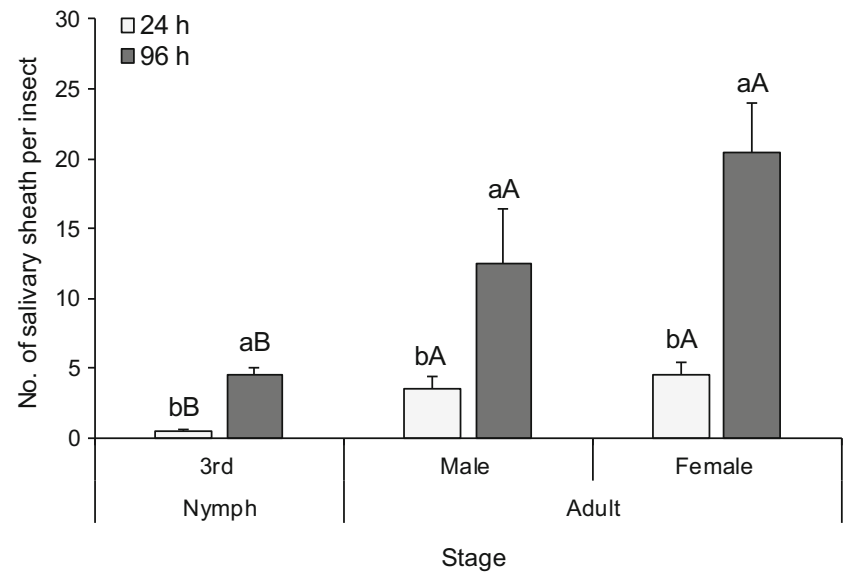

Fig 1 Feeding activity of nymphs and of adults Runibia perspicua feeding on Brunfelsia australis immature fruit, in the laboratory. Means followed by the same lowercase letter (between the two times intervals) do not differ significantly $(P<0.05)$ using Student's $t$ test; means followed by the same uppercase letter (between the three stages) do not differ significantly $(P<0.05)$ according to Tukey test. 


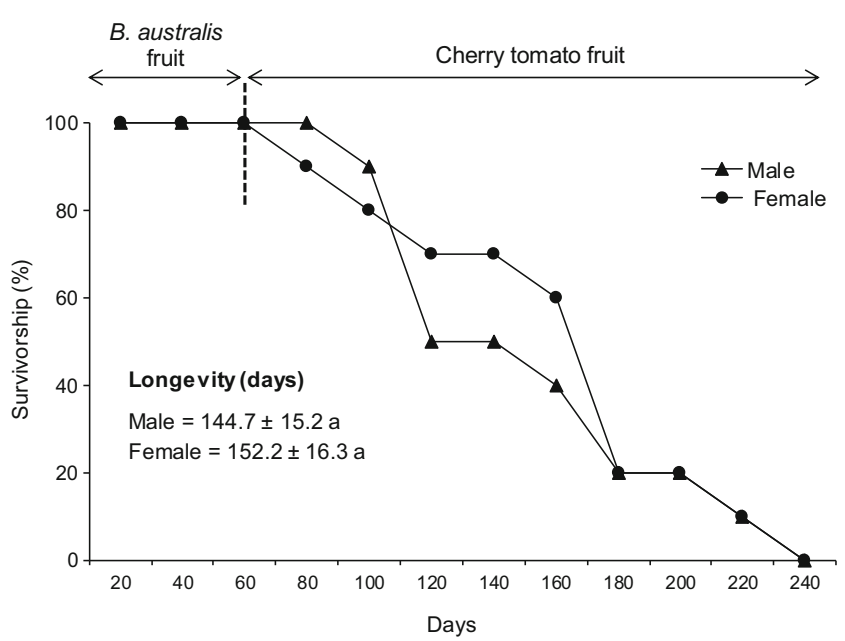

Fig 2 Survivorship (\%) and total longevity (mean \pm SE) up to day 240 of adult life of Runibia perspicua feeding on Brunfelsia australis immature fruit (up to day 54) and on cherry tomato fruit thereafter, in the laboratory. Means followed by the same letter do not differ significantly $(P<0.05)$ according to Student's $t$ test.

\section{Results}

\section{Laboratory studies}

Nymph Survivorship and Development. Nymphs of $R$. perspicua fed with different food sources were able to complete their development on immature fruits of B. australis (IFBA) and on raw shelled peanut (RSP), but not on immature pods of green bean (IPGB) or on immature fruits of privet (IFP) (Table 1). The lowest nymph mortality was observed on IFBA whether nymphs were raised isolated or in groups. Mortality of nymphs was high on RSP (90\%), and no nymphs complete development on IPGB and on IFP (Table 1).

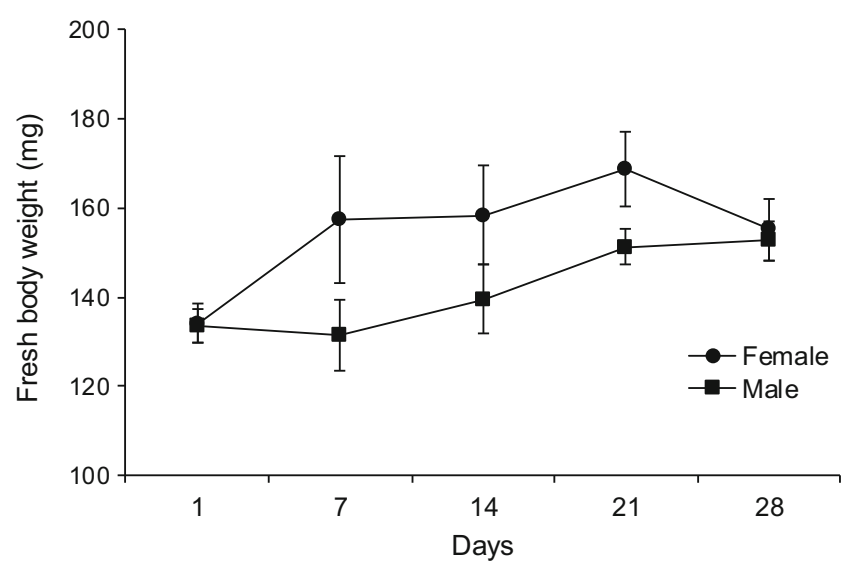

Fig 3 Fresh body weight (mg; mean $\pm \mathrm{SE}$ ) during the first five weeks of adult life of Runibia perspicua feeding on Brunfelsia australis immature fruit, in the laboratory.
Each nymphal stadium was much shorter on IFBA than on RSP. Total developmental time was similar between females and males feeding on IFBA (ca. 35 days, $n=9$ ) for nymphs raised isolated, and ca. 37 days (female + male) when nymphs were raised in groups $(n=83)$; on RSP, only one female reached adulthood, after 55 days (Table 1 ).

Fresh body weight of 1-day old adults did not show statistical differences between sexes from nymphs either raised isolated ( $t=1.431, P=0.236)$ or in groups $(t=1.107, P=0.283)$ on IFBA. However, fresh body weight of both females and males showed significantly greater weights when nymphs were raised isolated compared to those raised in groups (females: $t=-6.253, P<0.001$; male: $t=-10.706, P<0.001$ ) (Table 2).

Nymph and Adult Feeding Activity. The feeding activity of nymphs and of adults on IFBA showed highly significant differences among stages (nymph vs. adult) after 24 and $96 \mathrm{~h}$. At both times, adults deposited significantly (24 h, $F=29.96$, $P<0.001 ; 96 \mathrm{~h}, F=20.52, P<0.001)$ more stylet sheath on the immature fruits compared to nymphs (third instar) (Fig 1). Nymphs deposited significantly more stylet sheaths at $96 \mathrm{~h}$ compare to $24 \mathrm{~h}(t=-7.659, P<0.001)$, similarly to what occurred with adults (female: $t=-4.047, P<0.01$; male: $t=-2.465, P<0.05)$. Although adults deposited a much higher number of stylet sheath than nymphs, nymphs deposited nine times more sheaths on fruits after $96 \mathrm{~h}$ compared to $24 \mathrm{~h}$, whereas adults laid ca. four times more in this time interval (Fig 1).

Adult Survivorship, Longevity, Reproduction, and Body Weight. All adults survived up to day 54 when fed with IFBA; after that, cherry tomato was the food source and survivorship gradually decreased over time. However, males and females remained alive for a long time. For instance, after 140 days, $50 \%$ of males and $70 \%$ of females were still alive. The mean adult longevity on IFBA + cherry tomato fruit reached ca. 150 days and was similar between females and males ( $t=0.336, P=0.741$ ) (Fig 2). When fed on IFBA, females were able to reproduce ( $n=$ 6); mean preoviposition period was 20.5 days and the fecundity rate was $\mathbf{2 . 5}$ egg masses/female and $\mathbf{4 8 . 3}$ eggs/female; however, only $25.6 \%$ of the eggs hatched (data not shown).

Adult fresh body weight showed some differences between males and females fed with IFBA. In general, body weight for both sexes tended to increase during the first four weeks of adult life. For males, weight gain increased gradually over time during the four weeks, whereas for females, weight gain was higher during the first week, and they lost weight in the last week (Fig 3). 


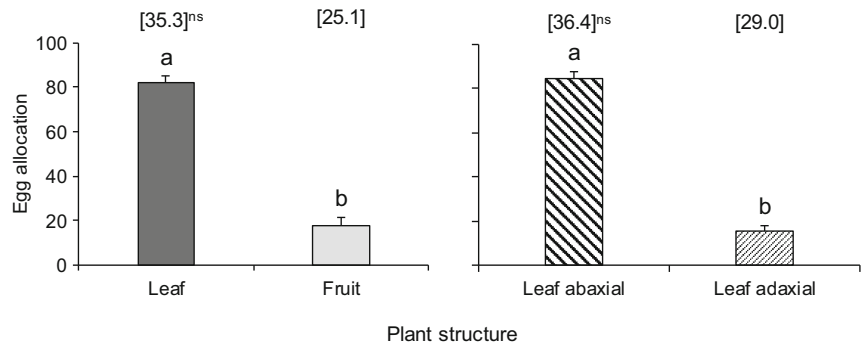

Fig 4 Egg allocation (\%) of Runibia perspicua on different structures of Brunfelsia australis plant in the field. Means (columns) with the same letters are not significantly different $(P<0.001)$ according to Pearson's chi-square test $\left(\chi^{2}\right)$. The number of eggs per mass (in brackets) was not significantly different according to Student's $t$ test $(P<0.05)$; ns = non-significant.

\section{Field studies}

Egg Mass Survey and Allocation on Different Plant Structures. The majority of egg masses laid by $R$. perspicua on $B$. australis plants were deposited on leaves compared to immature fruits $\left(\chi^{2}=40.96, P<0.001\right)$; egg masses on leaves were preferably deposited on the lower (abaxial) surface compared to the upper (adaxial) surface $\left(\chi^{2}=46.24\right.$, $P<0.001)$. The number of eggs per mass tended to be larger on leaves compared to those on fruits, and on the lower
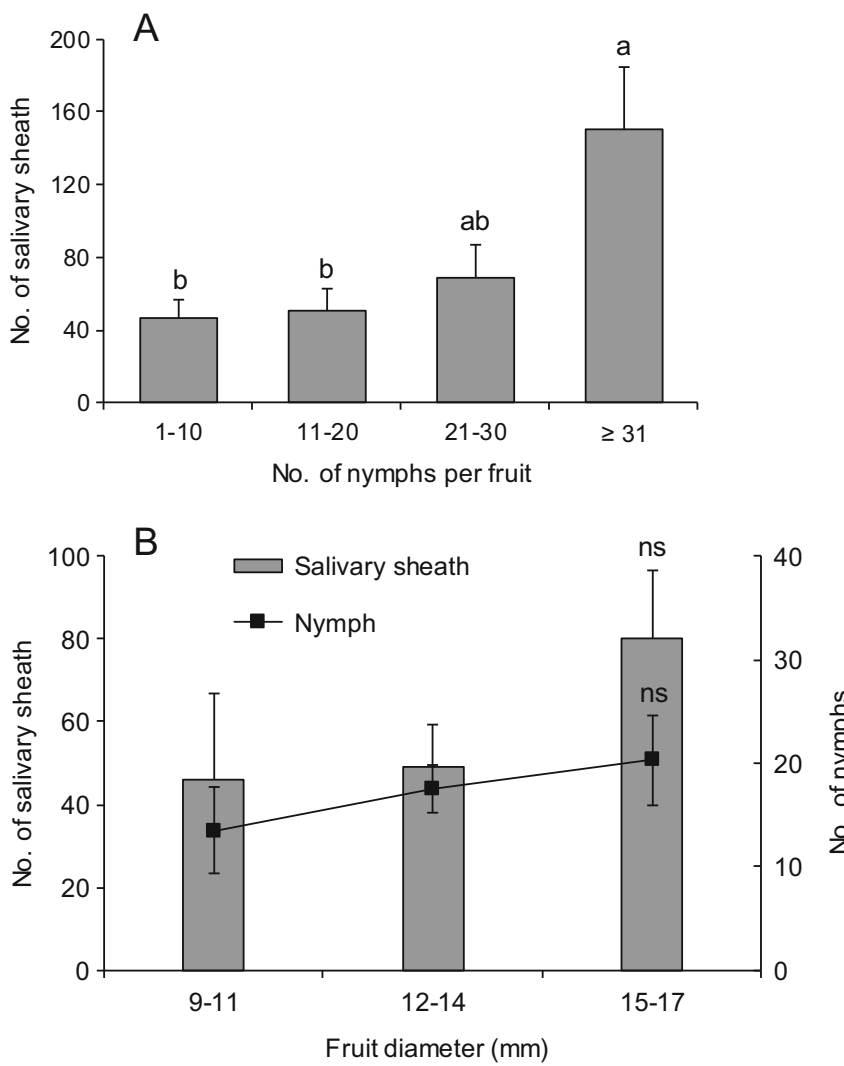

Fig 5 Runibia perspicua relationships with Brunfelsia australis immature fruit in the field: stylet sheath deposited by different numbers of nymphs per fruit (A) and numbers of nymphs and stylet sheaths per fruit of different sizes (B). Means followed by the same letter do not differ significantly $(P<0.05)$ according to Tukey testtest; $\mathrm{ns}=$ nonsignificant. compared to the upper surface; however, no statistical differences were observed $(t=1.660, P=0.10$; and $t=-0.985$, $P=0.333$, respectively) (Fig 4). Percentage of egg hatched varied from 70.9 on fruits to 78.6 on leaves.

Nymph Feeding Activity on Fruits. The feeding activity of nymphs of $R$. perspicua measured in number of stylet sheath deposited on fruits indicated that as the number of nymphs per fruit increased, the number of sheaths deposited also increased. Significant $(F=4.502, P<0.05)$ differences were observed between fruits with up to 20 nymphs per fruit compared to those with $\geq 31$ nymphs per fruit (Fig $5 A$ ).

Considering the size of the fruits (three sizes range from 9 to $17 \mathrm{~mm}$ in diameter), there was a tendency of bigger fruits to hold greater number of nymphs and greater number of stylet sheaths. However, no significant differences were observed among the size ranges compared (9-11, 12-14, and 15$17 \mathrm{~mm}$ ) either for the number of nymphs $(F=0.476, P=$ $0.625)$ or for the number of sheaths deposited $(F=1.656$, $P=0.207$ ) (Fig 5B).

\section{Discussion}

Results obtained in laboratory and field studies indicate that the lesser-known Neotropical stink bug $R$. perspicua successfully colonizes the ornamental tree $B$. australis. Apparently, plants of the genus Brunfelsia are preferred host plants, since the bug is reported to colonize them in several countries in the neotropics (Zwetsch \& Grazia 2001, Drechsel 2015). We also found $R$. perspicua on another species of ornamental Brunfelsia (B. pilosa Plowman) in the Passo Fundo area, but only in one occasion, two adults were found feeding on fruits. Adults of $R$. perspicua are known to be poor flyers and, when disturbed, do not fly but try to hide between or underneath leaves (Drechsel 2015). This behavior may explain the fact that usually adults are rarely observed on $B$. australis plants in the field. Despite the references of R. perspicua occurrence on pear (Monte 1939, Lima 1940, Bertels 1956, Buckup 1961), we were unable to find it on this plant species, and no literature reference was found on its 

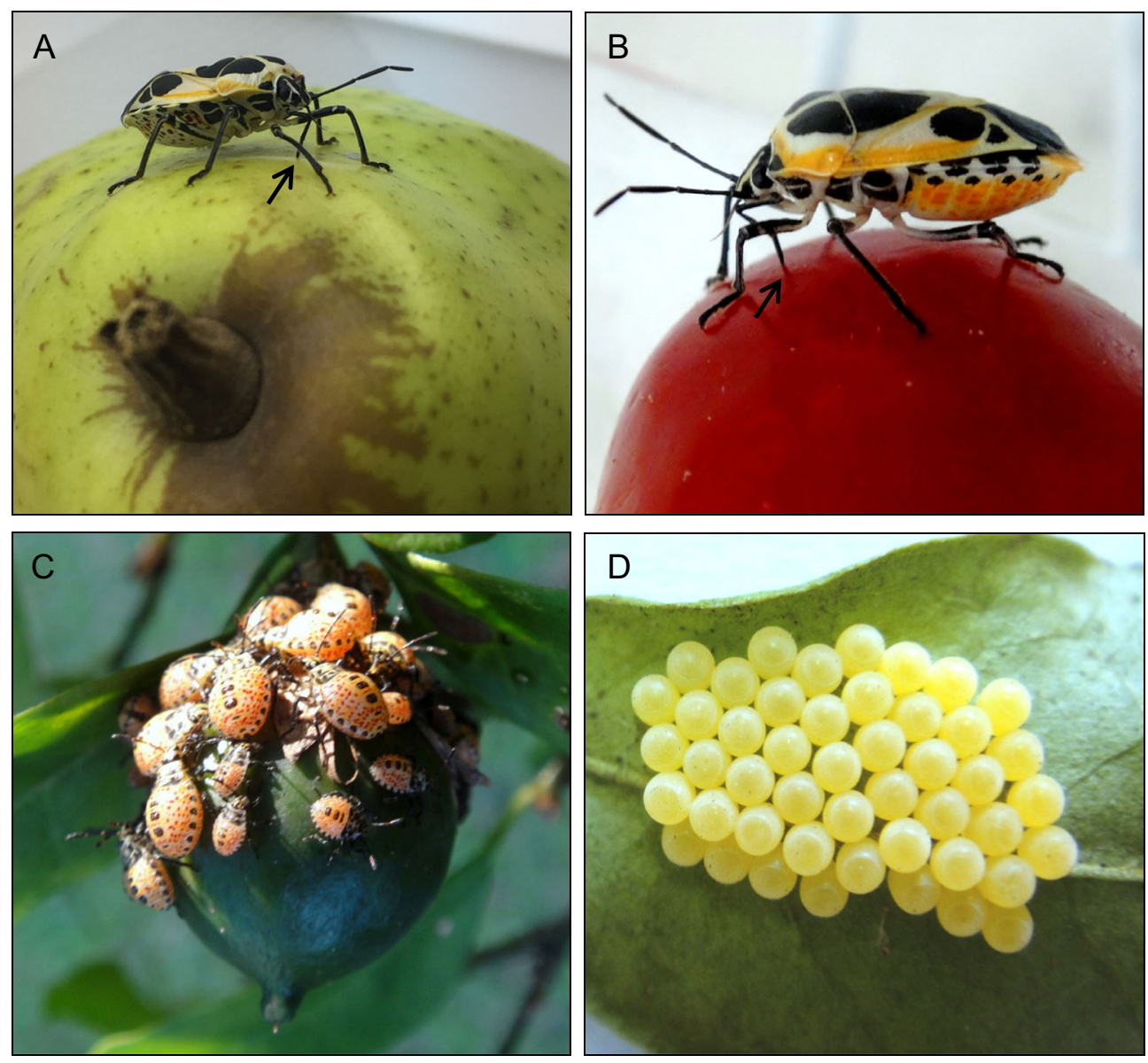

Fig 6 Adult of Runibia perspicua with stylets inserted into pear fruit tissue (A) and into cherry tomato fruit (B) in the laboratory (indicated by arrows); nymphs congregated on an immature fruit of Brunfelsia australis in the field (C); egg mass on the lower (abaxial) surface of a leaf of $B$. australis (D); adult with stylets inserted into the seeds of B. australis immature fruit (E) (indicated by arrow); and damage on seeds of $B$. australis caused by $R$. perspicua feeding activity (F) (indicated by arrows). Photos: $A$ and $E$ by TL; B-D, and F by ALMJ.
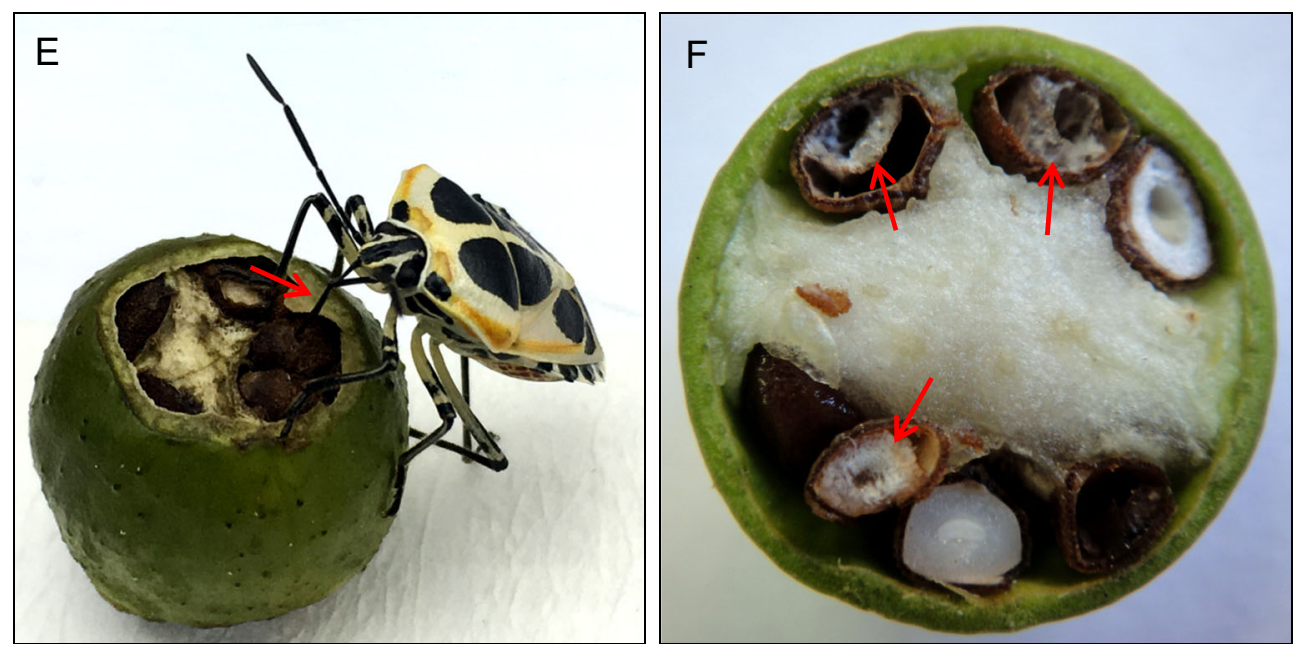

pest status on such fruit tree. Therefore, we suspect that it may colonize pear trees only occasionally and under special circumstances, such as when facing lack of its preferred host, Brunfelsia spp. Adults were observed in the laboratory with stylets inserted into the pear fruit tissue, probably ingesting nutrients (Fig 6A).

We were surprised to observe that $R$. perspicua, nymph and adult, fed and survived for a long time on cherry tomato fruit in the laboratory (Fig 6B). Adults were able to survive feeding exclusively on this food for over 170 days. This longevity is much greater than that compiled for some selected pest species of stink bugs (Panizzi 1997). Cherry tomato fruit provided nutrients to sustain adult life for a long period, and bugs produced eggs only when fed on $B$. australis.

The fact that nymphs were unable to complete development on other foods commonly used to rear stink bugs in the 
laboratory (except on RSP on which only one out of 10 nymphs completed development) further reinforces the observation that $R$. perspicua has limited food acceptability. Nymphs congregated and remained in clusters on B. australis fruits (Fig 6C).

This may cause nymphs to compete for food resources. Our data demonstrate that nymphs raised in groups showed greater mortality and resulting adults attained lower body weight as compared to those raised individually.

Egg mass allocation preferably on the lower (abaxial) leaf surface (Fig 6D) is common for pentatomid species that lay eggs on leaves, e.g., Nezara viridula (L.) (Rizzo 1976), and other heteropterans, such as the alydid Neomegalotomus parvus (Westwood) (Panizzi et al 1996), both on soybean, Glycine max (L.) Merrill. This behavior with egg masses less exposed may help to protect them from the action of natural enemies, from dehydration caused by sun light, and from being damaged by rainfall, as well. No egg parasitoids were found, and no adult parasites or predators were observed. The aposematic coloration presented by adults might be responsible for the avoidance of predators and parasitoids.

That the number of stylet sheaths on B. australis fruits increased as the number of nymphs per fruit increased and that a greater number of sheaths were deposited on bigger fruits were to be expected. However, there were no significant differences in these measures except that 31 or more nymphs deposited more stylet sheaths than did 20 or less nymphs. Similarly, up to $17 \mathrm{~mm}$ diameter, fruits did not significantly receive greater number of sheaths compared to smaller fruits (9-11 or 12-14 $\mathrm{mm} \varnothing$ ). These results suggest that nymphs aggregate on fruits in numbers independent of the fruit size.

Visual observations in the laboratory demonstrated that $R$. perspicua adult inserted its stylets into the seeds of B. australis immature fruits during feeding activities (Fig 6E). Moreover, we clearly observed that the stylets moved vigorously back and forth and deeply into the seed. This activity was reported for another seed feeder, Piezodorus guildinii (Westwood), feeding on soybean seed (Lucini et al 2016). According to Backus et al (2005), this behavior occurs during the cell rupturing feeding strategy, when piercing-sucking insects lacerate the cells (mechanical action) and secrete watery saliva rich in enzymes which macerate the cells (enzymatic action) (Miles 1972). These activities (mechanical + enzymatic) cause great damage in the seed tissues, as observed in cross sections of fresh IFBA (Fig 6F).

In conclusion, these laboratory and field studies with $R$. perspicua add novel information on this little studied aposematic Neotropical stink bug. Apparently, despite eventually feeding on plants of economic importance, its low abundance and low pest status may explain the lack of data available on its biology in the literature.
Acknowledgments We thank Natália Webber, Alice Agostinetto, and Júlio Minosso for help in the laboratory activities. We also thank Prof. Jocélia Grazia, Federal University of Rio Grande do Sul, for the insect identification and Prof. Branca A. M. Severo, University of Passo Fundo, for the plant identification.

Funding Information This study was partially supported by a National Council of Research and Technology of Brazil (CNPq) grant 471517/20127 to ARP. This study was also supported by Embrapa Unit at Passo Fundo, RS

Compliance with Ethical Standards This study was approved by the Publication Committee of the Embrapa National Wheat Research Center, Passo Fundo, RS, Brazil, under number 5467/2017.

\section{References}

Backus EA, Serrano MS, Ranger CM (2005) Mechanisms of hopperburn: an overview of insect taxonomy, behavior, and physiology. Annu Rev Entomol 50:125-151. https://doi.org/10.1146/annurev.ento.49. 061802.123310

Bertels A (1956) Entomologia Agrícola Sul-Americana. Ministério da Agricultura, Rio de Janeiro, Brazil, Série Didática 16, 485p

Biezanko CM, Bertholdi RE, Baucke O (1949) Relação dos principais insetos prejudiciais observados nos arredores de Pelotas nas plantas cultivadas e selvagens. Agrosciencia 2:156-213

Buckup L (1961) Os pentatomídeos do estado do Rio Grande do Sul (Brasil) Hemiptera-Heteroptera-Pentatomidae. Iheringia Ser Zool 16:1-24

Lima AMC (1940) Insetos do Brasil. $2^{\circ}$ Tomo, Capítulo XXII Hemípteros. Escola Nacional de Agronomia, Rio de Janeiro, Brasil, Sér. Didática 3, $351 \mathrm{p}$

Drechsel U (2015) Recent records and host plant reports of two species of Pentatomidae from Paraguay (Heteroptera: Pentatomidae). Paraguay Biodiversidad 2:7-11

Lucini T, Panizzi AR, Backus EA (2016) Characterization of an EPG waveform library for redbanded stink bug, Piezodorus guildinii (Hemiptera: Pentatomidae), on soybean plants. Ann Entomol Soc Am 109:198210. https://doi.org/10.1093/aesa/sav156

Miles PW (1972) The saliva of Hemiptera. Adv Insect Physiol 9:183-255. https://doi.org/10.1016/So065-2806(08)60277-5

Monte O (1939) Hemípteros fitófagos. O Campo 10:58-61

Panizzi AR (1997) Wild hosts of pentatomids: ecological significance and role in their pest status on crops. Annu Rev Entomol 42:99-122. https://doi.org/10.1146/annurev.ento.42.1.99

Panizzi AR, Hirose E, Oliveira EDM (1996) Egg allocation by Megalotomus parvus (Heteroptera: Alydidae) on soybean. An Soc Entomol Brasil 25: 537-543

R Development Core Team (2016) R: a language and environment for statistical computing. R foundation for statistical computing, Vienna

Rider DA (1991) Rhyssocephala, new genus, with the description of three new species (Heteroptera, Pentatomidae). J N Y Entomol Soc 99:583610

Rizzo HF (1976) Hemípteros de interés agrícola. Editorial Hemisferio Sur, Buenos Aires 69p

Silva FAC, Panizzi AR (2008) The adequacy of artificial oviposition substrates for laboratory rearing of Piezodorus guildinii (Westwood) (Heteroptera, Pentatomidae). An Soc Entomol Brasil 52:131-134

Silva AGDA, Gonçalves CR, Galvão DM, Gonçalves AJL, Gomes J, Silva MN, Simoni L (1968) Quarto Catálogo dos Insetos que Vivem nas Plantas do Brasil-Seus Parasitas e Predadores. Parte II, Tomo 1, Ministério da Agricultura, Rio de Janeiro, Brasil, 622p

Zwetsch A, Grazia J (2001) Revisão do gênero Runibia (Heteroptera, Pentatomidae, Pentatomini). Iheringia Ser Zool 91:5-28 